Research article

\title{
SURGICAL TECHNIQUE USING AN IMPROVISED PERITONEAL CATHETER IN AN EXPERIMENTAL NON-UREMIC RABBIT MODEL OF PERITONEAL DIALYSIS
}

\author{
KRSTIĆ Slobodan ${ }^{1,5}$, TRBOJEVIĆ-STANKOVIĆ Jasna ${ }^{2,5}$, ŽUNIĆ Snežana ${ }^{3,5 *}$, \\ JOVANOVIĆ Nataša ${ }^{4}$, STOJIMIROVIĆ Biljana ${ }^{4,5}$
}

\begin{abstract}
${ }^{1}$ Institute for Digestive Diseases, Clinical Center of Serbia, Belgrade, Serbia; ${ }^{2}$ Clinic of Urology, University Hospital Center "Dr Dragisa Misovic", Belgrade, Serbia; ${ }^{3}$ Institute of Pathophysiology, Belgrade, Serbia; ${ }^{4}$ Clinic of Nephrology, Clinical Center of Serbia, Belgrade, Serbia; ${ }^{5}$ School of Medicine, University of Belgrade, Belgrade, Serbia
\end{abstract}

(Received 26 ${ }^{\text {th }}$ March; Accepted $1^{\text {st }}$ June 2015)

\begin{abstract}
Experimental models have strongly contributed to the comprehension of the processes of peritoneal damage that take place during peritoneal dialysis treatment in human patients. A variety of peritoneal dialysis models have been developed, mostly using rats and rabbits.

In this study we present the successful development of a custom-made improvised peritoneal catheter for an experimental non-uremic rabbit model of peritoneal dialysis.

A detailed description of the surgical technique of peritoneal catheter implantation, care and removal is provided.

This innovative approach to constructing a peritoneal catheter in rabbit animal model of peritoneal dialysis is easy, reproducible and inexpensive. The surgical technique applied provided adequate tissue samples for both light and electron microscopy.
\end{abstract}

Key words: experimental model, improvised peritoneal catheter, peritoneal dialysis, rabbit, surgical technique

\section{INTRODUCTION}

Peritoneal dialysis (PD) is an accepted and still growing treatment for end-stage renal failure patients. However, it is now widely recognized that several constituents of conventionally used peritoneal dialysis solutions are bioincompatible and play a role in the development of a chronic inflammatory condition in the peritoneal cavity of these patients, leading to ultrafiltration failure, peritonitis and peritoneal fibrosis [1]. The conventional solution is a glucose-containing, lactate-buffered solution with $\mathrm{pH} 5.2$

Corresponding author: e-mail: nzunic@med.bg.ac.rs 
and glucose degradation products that are formed during sterilization. A number of in vitro studies have determined which components of conventional dialysis fluids are responsible for bioincompatibility, but extrapolation from these data to in vivo effects is difficult [2].

Studies on the effects of dialysis fluid on the peritoneal membrane in humans are still a challenge due to ethical and technical limitations, as tissue samples can be obtained solely when placing or removing the peritoneal catheter. The use of animal models can provide information about peritoneal response to PD fluid exposure, mimic dynamic changes in solution composition during PD and evaluate mechanisms that regulate transperitoneal transport of water and solutes [3].

The rabbit has become a classical experimental animal in immunology, pharmacology, physiology and clinical medicine [4-7]. Among its attributes for this distinction are convenient size, ease of handling and management, low cost of acquisition and care, reproducibility and reliability of experimental results, availability of anatomical, biochemical and physiological data, genetic uniformity, docility and predictable behavior.

We have recently developed an experimental rabbit model of exposure of the peritoneal membrane to dialysis fluids, which mimics the process of peritoneal damage that occurs during PD in human patients $[8,9]$.

The aim of this study is to describe a novel surgical approach to placement and handling of a custom-made peritoneal catheter in a rabbit model of PD.

\section{ANIMALS AND METHODS}

Seventeen healthy Chinchilla male and female rabbits, weighing $2739 \pm 388 \mathrm{~g}$ at the beginning of the study were included in the experiment. The study was done at the Institute of Pathophysiology, School of Medicine, Belgrade, during 2006. Animals were kept in individual cages and received standard rabbit pellets (Veterinary Institute, Subotica, Serbia) and water ad libitum. All rabbits were allowed at least five days to adapt to the new living conditions prior to surgical peritoneal catheter insertion. The animals were prevented from taking food and water one day before surgery and they were allowed to feed and drink ad libitum the following day. The study lasted for five weeks (one week of recovery and four weeks of dialysis), during which time a diary of animal behavior was kept. Detailed information on body mass, body temperature, food intake, diuresis, defecation, antibiotics administration, other treatments and interventions when performed (wound toilette, catheter suturing etc.) were kept.

All experimental procedures were performed in accordance with the European Council Directive (86/609/EEC), and were approved by the Animal Care Committee of the University of Belgrade. 


\section{Anesthesia procedure}

For catheter implantation and removal the rabbits were anesthetized intramuscularly with Zoletil (Virbac, France), $15 \mathrm{mg} / \mathrm{kg}$ body mass and Xylazine (Bayer, Germany), $5 \mathrm{mg} / \mathrm{kg}$ body mass in different hind limbs. Such dosage was sufficient for adequate catheter implantation and removal, without any adverse effects on the animals.

\section{Surgical technique of peritoneal catheter placement and fixation}

At the beginning of our study we used double-lumen central venous catheters (Arrow International Inc. USA Product No.CV-17702-E) as peritoneal catheters. The implantation technique of these catheters was a modified version of the procedure described in the literature [10], and it was performed as described in the following text.

Anesthesia was inducted and animals were shaved on the dorsal part of the neck, between the ears and scapulae and below the left costal arch (upper left hemiabdomen). The surgical field was prepared in a standard way. Then, a vertical incision of $3-4 \mathrm{~cm}$ was made, starting 2-3 cm distally from the left costal arch edge, 4-5 cm from median abdominal line and parallel with it.

The subcutaneous layer was then entered partly sharply partly bluntly, with thoracic drain No 16 stylet, with rotating and rectangular movements, to form a tunnel from the abdominal to the neck region. The exit site of the catheter was made at the dorsal part of the neck, between the ears (Figure 1a). The catheter was then placed over a stylet and carefully advanced back through the tunnel, from the neck to the abdomen (Figure 1b). The abdominal muscles were split sharply or bluntly to access the peritoneal cavity. Immediately after dissecting the peritoneum and opening the peritoneal cavity, biopsies of the peritoneal tissue were taken from the diagonal edges. The intraperitoneal segment was slid off the stylet and the catheter was placed on the floor of the peritoneal cavity.

The peritoneum was closed with a running suture using nonabsorbable monofilament Ethilon 4-0 (Ethicon, Germany). The same suture was used to fix the catheter in the tissue at the entrance and exit sites. The muscles were closed with absorbable Vicril 3-0 (Ethicon, Germany), and the fasciae with running suture using Ethilon 3-0 (Ethicon, Germany). The skin was closed with simple interrupted non-absorbable sutures using Prolene 3-0 (Ethicon, Germany) (Figure 1c). Finally, sterile gauze was placed at both entrance and exit sites of the catheter and fixed with bandage wrapped circularly around the animal (Figure 1d).

The double-lumen central venous catheters (used as the peritoneal catheters) were placed in this way in four animals. However, the branches of the catheter stretched over the animals' ears, irritated them and were easily reachable. In the first few postoperative days, the rabbits bit off the external catheter branches or even pulled the whole catheters out, even though they were fixed at both ends. These catheters 
could not be shortened since they had an original extension for attaching infusion systems on their exit end.
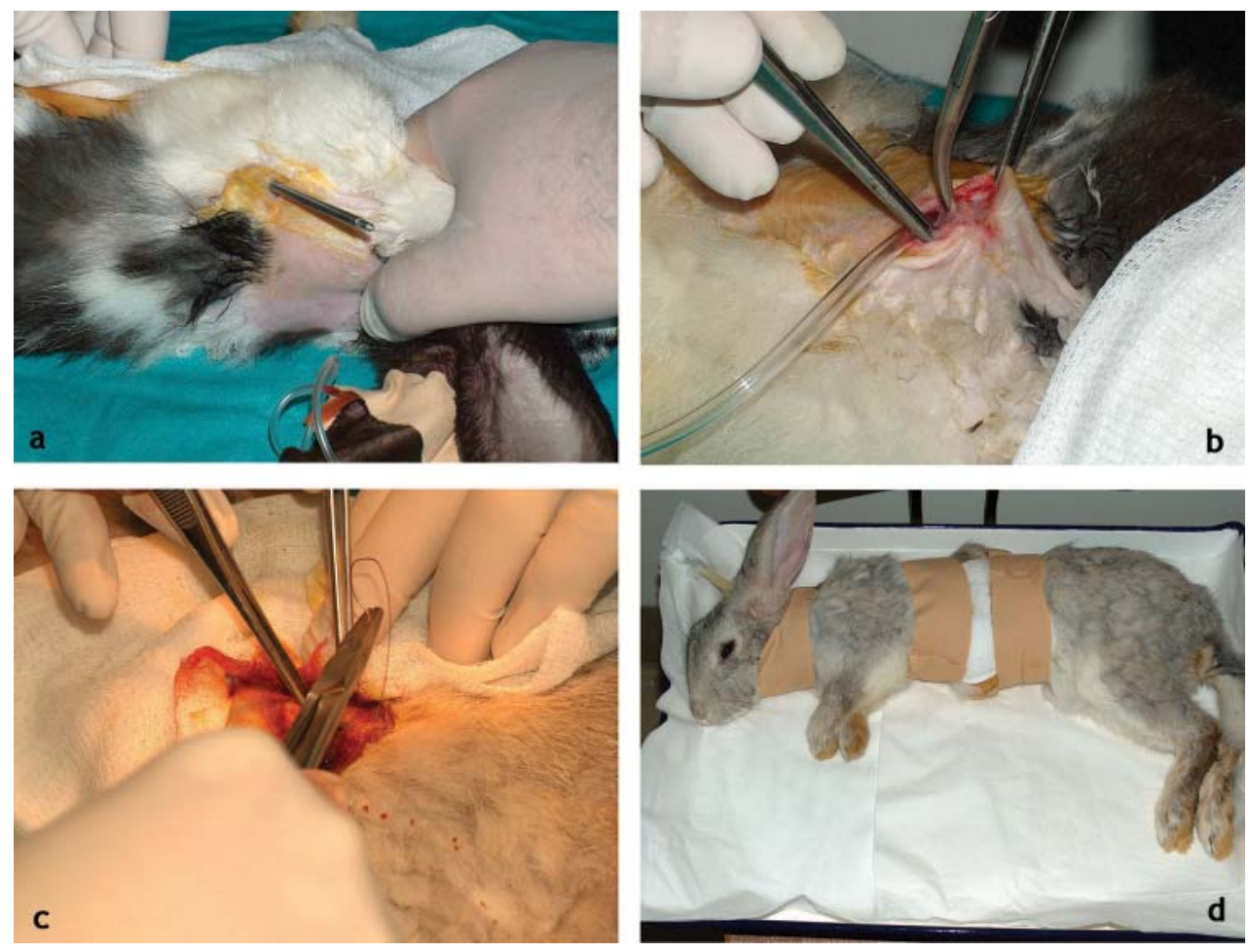

Figure 1. Surgical technique of peritoneal catheter placement-1

a. Advancing stylet through the tunnel to the exit site between the ears; $\mathbf{b}$. Placement of the peritoneal catheter; c. Closing the wound; $\mathbf{d}$. Securing the entrance and exit site of the catheter

We, therefore, had to modify this procedure. During the further course of our study we used a part of the Tro-soluset infusion set (Troge Medical GMBH, Hamburg, Germany), initially shortened at $45 \mathrm{~cm}$, as dialysis catheter (Figure 2a). Anesthesia, shaving, surgical field preparation, cutaneous incision and tunneling were all performed as previously described. The shortened infusion set - catheter was placed over a stylet and advanced through the preformed tunnel. Even though the catheter was made of very soft plastic, since the intraperitoneal part was sharply cut, we protected its apical part with $1 \mathrm{~cm}$ of soft rubber from the infusion set (Figure $2 \mathrm{~b}$ ).

The rubber cap was pulled over the catheter apex in order to avoid any contact with the peritoneal cavity and its organs. Then, four holes $(2-3 \mathrm{~mm}$ in diameter each) were made with surgical scissors at the end part of the catheter, near the rubber cap (Figure 2c). The peritoneal cavity was then accessed as previously described. The catheter (shortened and adjusted to the animals' size) was placed at the floor of the peritoneal cavity. The exit site of the catheter was at the dorsal part of the neck, between the ears. The exit part of the catheter was adapted by adding a two-way stopcock for easier application of antibiotics and heparin (Figure $2 \mathrm{~d}$ ). 

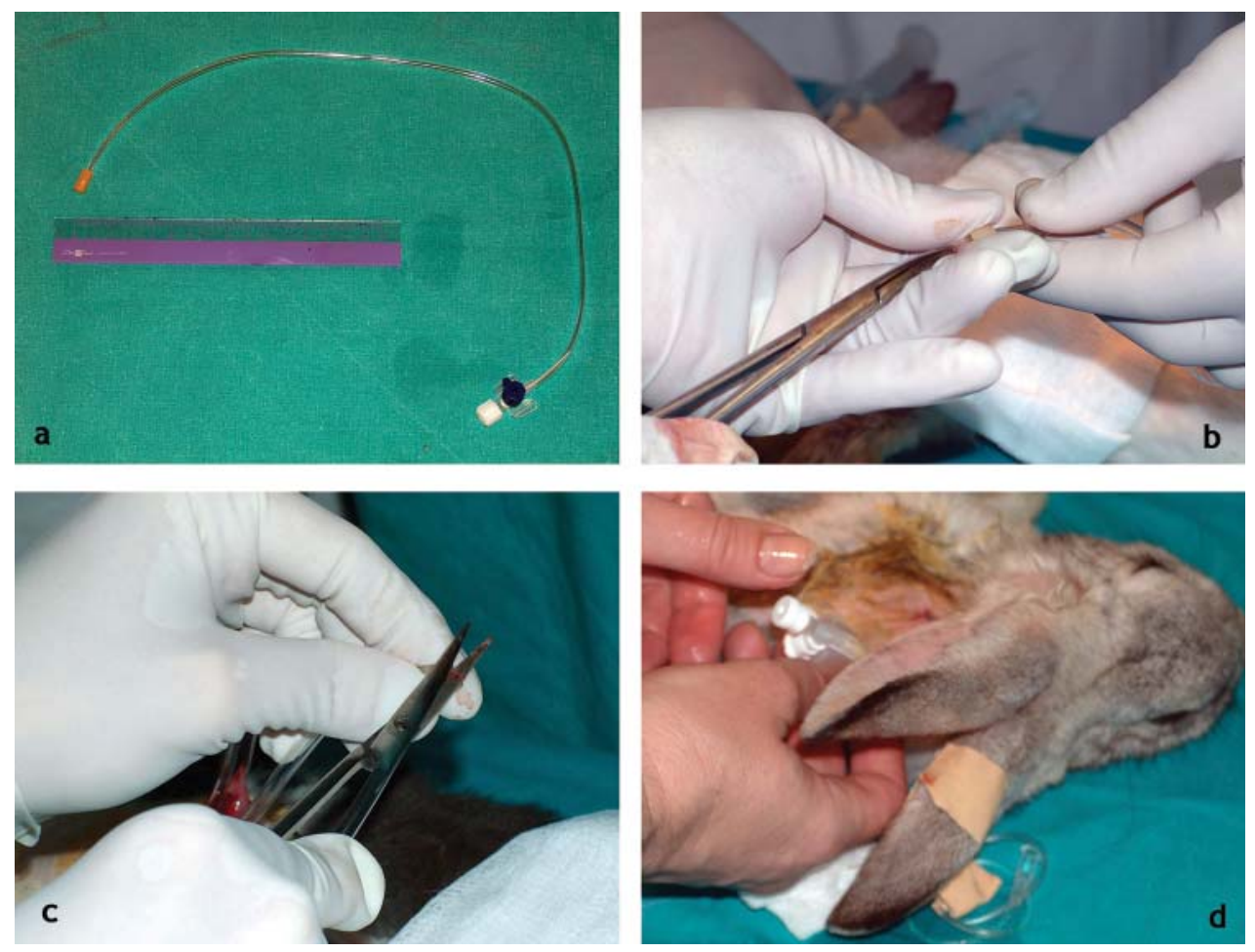

Figure 2. Surgical technique of peritoneal catheter placement-2

a. Tro-soluset infusion set (Troge Medical GMBH, Hamburg, Germany), initially shortened at $45 \mathrm{~cm}$, as dialysis catheter; $\mathbf{b}$. Protecting the catheter apex with a soft rubber cap from the infusion set; c. Making holes at the end part of the peritoneal catheter with surgical scissors; d. Adaptation of the exit site of the catheter by adding a two-way stopcock for easier application of antibiotics and heparin

The wounds were then closed as previously described.

In order to prevent obstruction, the catheters were instilled with $10 \mathrm{IU} /$ day of heparin sodium (Heparin ${ }^{\circledR}$, Galenika a.d, Belgrade, Serbia), starting immediately following the insertion and continuing throughout the whole study period.

Infection was prevented with cefuroxime (Nilacef, Hemofarm, Serbia and GlaxoSmithKline, England). Based on the protocols by Peng et al. [11] and Mortier et al. [12], $75 \mathrm{mg}$ of antibiotic was applied intramuscularly, b.i.d, for three days prior to catheter placement and three days following catheter removal. During dialysate instillations, $75 \mathrm{mg} /$ day of antibiotic were instilled into the peritoneal cavity via the peritoneal catheter.

\section{Peritoneal tissue sampling and catheter removal}

Seven days after the catheter insertion dialysate instillations were started. After 4 weeks of daily instillations, the catheter was removed and peritoneal tissue samples obtained for histological analysis. 
For catheter removal a new incision, $2-3 \mathrm{~cm}$ long, was made in front of the previous one. We opted for this approach because of the existing scar and to avoid possible damage to the peritoneum when collecting tissue samples. The peritoneum was accessed in the same way as previously described. Since the peritoneal tissue is extremely fragile and susceptible to mechanical irritations and environmental factors, tissue sampling was performed as soon as the peritoneum was uncovered. Two tissue samples, one for light and one for electron microscopy, were taken. The catheter was then identified. In four animals it first had to be carefully freed from the omentum which was wrapped around its tip. The rubber apical part of the catheter was cut out and the catheter was pulled out through the tunnel at its exit site on the dorsal part of animals' neck. The abdominal wound was then closed as previously described.

\section{RESULTS}

Of the seventeen animals initially included in this experiment, four animals bit off the inserted peritoneal catheter. Thus, thirteen animals $(76.47 \%$ ) fully completed the study follow-up period of five weeks - one week recovery following catheter implantation and 4 weeks of dialysate instillation. The overall survival rate was $100 \%$.

No animals were lost due to surgical intervention itself and all rabbits made complete recovery immediately after surgery.

During the follow up period no wound infection appeared in none of the animals. A single episode of peritonitis was suspected when one rabbit developed diarrhea on the fourth day of dialysate instillation. Although its body weight loss was only $100 \mathrm{~g}$, i.e. less than $5 \%$ of total body weight, and body temperature never exceeded $39.5 \mathrm{C}^{\circ}$, the animal was treated with cefuroxime intraperitoneally and gentamicin intramuscularly for 7 days. Diarrhea resolved after three days of treatment and the rabbit completed the follow-up period.

No catheter obstruction was recorded during the follow-up period, suggesting that heparinization was adequately performed.

\section{DISCUSSION}

Patients treated with PD are at risk of development of ultrafiltration failure and peritonitis, resulting in the termination of PD treatment. The relative unphysiological composition of the currently used standard peritoneal dialysis fluids is considered to be a major cause for the development of morphologic changes of the peritoneal membrane. The main alterations of the peritoneal membrane are fibrosis and angiogenesis, ultimately resulting in ultrafiltration failure and probably contributing to changes in local defense mechanisms with the associated increased risk of peritonitis [2]. In recent years, a major research focus has become the development of new and improved PD solutions [13,1]. 
Obtaining samples of human peritoneal tissue to analyze effects of peritoneal dialysis is difficult due to numerous ethical constraints. Therefore, animal models of peritoneal dialysis have been introduced and used to investigate the consequences of peritoneal exposure to the dialysate. A number of animal models have been used so far, mostly using rats and rabbits as experimental animals.

Since we could not provide an original peritoneal catheter for use in animals, we opted to improvise one. We constructed an original peritoneal catheter using part of the infusion system and this solution gave excellent results. Animals tolerated it well, it did not cause any infections, dialysate instillations were easily performed and even dialysate removal was possible, which might enable further studies of peritoneal membrane function.

The most important problems in chronic PD animal models are infection and catheter obstruction [14]. We observed none of these complications in animals included in our study.

Definition of peritonitis in animal models is still arbitrary. It is suspected when there is more than $5 \%$ daily body weight loss, fever and diarrhea. The criteria most often used for peritonitis diagnosis are positive dialysate culture and dialysate WBC count higher than 1000 cells $/ \mathrm{mm}[3,12,15]$. There are several different strategies in use to prevent and treat peritonitis [16], and we opted for prophylactic administration of cefuroxime during the entire study period, as suggested by Mortier et al. [12]. This approach successfully prevented intraperitoneal infection in animals used in our model of chronic peritoneal dialysate exposure. Only one rabbit showed signs of possible peritoneal infection, which was successfully treated.

Use of heparin to prevent catheter clogging is followed by undesirable effects, such as modulation of inflammatory cells activity, cells proliferation, and increased synthesis of extracellular matrix and neoangiogenesis, which might affect the results of further hystological analysis of the tissue [17]. Even though we are aware of these side effects of heparin, we still preferred it to omentectomy, since it better mimics real-life clinical situations when heparin is used in humans to solve malfunctioning of peritoneal catheters. The use of heparin-coated catheters seems to be the method of choice of peritoneal access [18], but we could not provide them for this study.

We presented an innovative approach to constructing peritoneal catheters in the rabbit animal model of peritoneal dialysis which is easy, reproducible and inexpensive. The surgical technique described in this paper provided adequate tissue samples which could be easily prepared for both light and electron microscopy.

\section{Acknowledgments}

This study was performed within a research project funded by the Ministry of Health and Environmental Protection, Republic of Serbia, No. 145070. The authors would like to express their deepest gratitude and appreciation to Vladimir Miljković, laboratory technician, and Mira Pavlović, animal keeper, for their valuable help in this research. 


\section{REFERENCES}

1. Fabbrini P, Zareie M, ter Wee PM, Keuning ED, Beelen RHJ, van den Born J. Peritoneal exposure model in the rat as a tool to unravel bio(in)compatibility of PDF. Nephrol Dial Transpl 2006, 21 (suppl 2):ii8-ii11.

2. Stavenuiter AWD, Farhat K, Schilte N, ter Wee PM, Beelen RHJ. Bioincompatible impact of different peritoneal dialysis fluid components and therapeutic interventions as tested in a rat peritoneal dialysis model. Int J Nephrol 2011, 2011:742196.

3. Müller-Krebs S, Zhang W, Kihm LP, Reiser J, Nawroth PP, Schwenger V. Glucose effects on the peritoneum: what can we learn from rodent models? Exp Clin Endocrinol Diabetes 2012, 120 (4):197-198.

4. Mashiah A, Marcus L, Savin H, Margel S. The rabbit as an animal model for haemoperfusion: surgical preparation and use. Lab Anim 1984,18 (1):26-32.

5. Vučević Danijela, Milovanović I., Mladenović D., Žunić-Božinovski Snežana, Radosavljević Tatjana, Stojanović Jasna, Pešić B.Č. and Đorđević-Denić Gordana: The effect of tocopherol on serum lipid profile in pulmonary emphysema induced by hypercholesterolemic diet. Acta Vet-Beograd 2007, 57: 303-20

6. Žunić-Božinovski Snežana, Žunić Svetlana, Mladenović Đorđević Aleksandra, Ruždijić Sabera, Kanazir Selma: Apoptotic clearance in rabbits with experimental pulmonary emphysema. Acta Vet-Beograd 2011, 61 (5-6): 513-22

7. Horňák Slavomír, Harvanová Denisa, Ledecký Valent, Hluchý Marian, ValenčákováAgyagosová Alexandra, Amrichová Judita, Rosocha Ján, Vaško Gabriel, Švihla Róbert, Petrovič Vladimír. Reparation of chondral defects in rabbits by autologous and allogenous chondrocytes seeded on collagen/hyaluronan scaffold or suspended in fibrin glue. Acta Vet-Beograd 2014, 64 (1):61-72.

8. Žunić-Božinovski S, Stojimirović B, Laušević Ž, Krstić S, Trbojević-Stanković J, Jovanović N. Modification of peritoneal dialysis model on rabbits: A pilot study. Srp Arh Celok Lek 2008, 136 (Suppl 1):38-43.

9. Zunic-Bozinovski S, Lausevic Z, Krstic S, Jovanovic N, Trbojevic-Stankovic J, Stojimirovic B. An experimental, non-uremic rabbit model of peritoneal dialysis. Physiol Res 2008, 57 (2):253-260.

10. Zweers MM, Douma CE, de Waart DR, van der Wardt AB, Ho-dac-Pannekeet MM, Krediet RT, Struijk DG. The standard peritoneal permeability analysis in the rabbit: a longitudinal model for peritoneal dialysis. Perit Dial Int 1999, 19 (1):56-64.

11. Peng WX, Guo QY, Liu SM, Liu CZ, Lindholm B, Wang T. Comparison of three chronic dialysis models. Adv Perit Dial 2000, 16:51-54.

12. Mortier S, De Vriese AS, Leyssens A, Vanacker NJ, Faict D, Cornelissen M, De Ridder L, Lameire NH. Antibiotic administration in an animal model of chronic peritoneal dialysate exposure. Perit Dial Int 2003, 23 (4):331-338.

13. ter Wee PM, Beelen RH, van den Born J. The application of animal models to study the biocompatibility of bicarbonate buffered peritoneal dialysis solutions. Kidney Int Suppl 2003, 88:S75-S83.

14. Choi J, Credit K, Henderson K, Deverkadra R, Vanpelt HM, He Z, Flessner MF. Antibiotic prophylaxis in an animal model of chronic peritoneal exposure. Perit Dial Int 2006, 26 (2):249-258. 
15. Mortier S, Faict D, Schalkwijk CG, Lameire NH, De Vriese AS. Long-term exposure to new peritoneal dialysis solutions: Effects on the peritoneal membrane. Kidney Int 2004, 66 (3):1257-1265.

16. Zhou JY, Xu PF, Chen H, Yu YS, Chen YG. Therapeutic effect of ceftazidime in a rabbit model of peritonitis caused by Escherichia coli producing CTX-M-14 extended-spectrum beta-lactamase. Zhonghua Jie He He Hu Xi Za Zhi 2005, 28 (10):689-693.

17. De Vriese AS, Mortier S, Lameire NH. Non anticoagulant effects of heparin: implications for animal models of peritoneal dialysis. Perit Dial Int 2001, 21 (Suppl 3):S354-S356.

18. De Vriese AS, Mortier S, Cornelissen M, Palmans E, Vanacker NJ, Leyssens A, Faict D, De Ridder L, Lameire NH. The effects of heparin administration in an animal model of chronic peritoneal dialysate exposure. Perit Dial Int 2002, 22 (5):566-572.

\title{
HIRURŠKA TEHNIKA KOJA KORISTI IMPROVIZOVANI PERITONEUMSKI KATETER U EKSPERIMENTALNOM NEUREMIČNOM MODELU PERITONEUMSKE DIJALIZE NA KUNIĆIMA
}

\author{
KRSTIĆ Slobodan, TRBOJEVIĆ-STANKOVIĆ Jasna, ŽUNIĆ Snežana, \\ JOVANOVIĆ Nataša, STOJIMIROVIĆ Biljana
}

Korišćenje eksperimentalnih modela je od posebnog značaja za razumevanje procesa oštećenja peritoneuma, koji se dešavaju u toku tretmana peritoneumskom dijalizom kod bolesnika. Razvijen je veliki broj eksperimentalnih modela peritoneumske dijalize, a većina njih koristi miševe i kuniće kao eksperimentalne životinje.

U ovoj studiji prikazan je naš doprinos u razvoju improvizovanog peritoneumskog katetera koji se može koristiti u eksperimentalnom neuremičnom modelu peritoneumske dijalize na kunićima. Dat je detaljan opis hirurške tehnike implantacije i uklanjanja peritoneumskog katetera.

Ovaj inovativni pristup razvoju peritoneumskog katetera u eksperimentalnom modelu peritoneumske dijalize je jednostavan, reproducibilan i jeftin. Primenjena hirurška procedura može da posluži za dobijanje odgovarajućih uzoraka tkiva za svetlosnu i elektronsku mikroskopiju. 